\title{
Actualizing Political Science
}

\author{
Joely Proudfit
}

$T$

hank you for the opportunity to respond to the essay by Kennan Ferguson. Ferguson poses some very provocative questions and suggests some strategies that align with my perspectives. However, I was struck from the beginning by the title Why Does Political Science Hate American Indians because it immediately neutralizes the focus to some generic, nameless set of folks. It reminded me of a recent chapter Concrete Teepees, Faceless Bureaucrats, and Learned Helplessness written by a colleague. She moves, most directly, to "name" the faceless bureaucrats with oversight of Indian Affairs and by doing so she changes the direction of the conversation from theoretical, philosophical musings to a call for action. My conversations with her suggest that like many American Indians in the later years of their careers, she is anxious for real change.

I had the privilege to count Vine Deloria as a friend and advisor and it is clear that his work dominated the intellectual conversations merging American Indians and political science for decades. While those conversations form a significant part of my own thinking, writing, and activism, it is this platform for action that calls my attention. My recent work on identity, privileging, and appropriation in higher education is a beginning, but the real work, I believe, is in the day-to-day role modeling that all American Indians who seek to work in higher education assume when they walk through the door of that ivory tower, whether as faculty or administrator. So, I would suggest that modifying Ferguson's opening statement and instead of saying that Native Americans are missing from political science, I suggest that they are busy actualizing political science. By that I mean that for traditional cultures, it is more important to work on the day-to-day political issues that affect tribal governments than it is to publish articles that will be read by other political scientists and, therefore, not likely to change any of the perspectives of legislators or tribal leaders.

\footnotetext{
Joely Proudfit is Director of the California Indian Culture \& Sovereignty Center and Department Chair of American Indian Studies at California State University, San Marcos (jproudfi@csusm.edu).
}

Also, I believe that we should note that very few American Indians actually complete a terminal degree to qualify for entry level positions in higher education. The majority of those who do so seek a field where change is more readily evident. By acquiring credentials to become a teacher or school administrator, for example, individuals are able to impact American Indian communities daily as they seek to provide the skills, knowledge, and abilities that American Indian youth need if they are to become productive members of a tribal community. So from my perspective, it is a question of sheer numbers, or more specifically, lack of numbers. This is the target of my own activism. As Ferguson notes in his first point, his target audience is political scientists. These professors are the gatekeepers to the profession and, I agree, that as long as these perspectives remain stable, American Indians will not pursue political science in post-secondary education.

I applaud Ferguson's understanding and description of identity and its correlative interest in political science. Most people would move to the general assumption that if you are Diné then you couldn't possibly be interested in the European Union; I have a colleague who is an Ivy League-trained Faulkner scholar who is, incidentally, Choctaw. Most people would expect him to be an expert only in American Indian Literature.

Additionally, Ferguson's characterization that political scientists view American Indians as a minority, similar to other minorities, as they catalogue and project theses of a Nation State, is on target. American Indian sovereign nationhood is ignored-again. The failure of the schooling in America to recognize the legitimacy of tribal nations has fostered this perspective and nowhere is it more evident than in Congressional members who propose bills, virtually every year, to abrogate Native treaties.

I propose that graduate students who would have been interested in Political Science are not deeply involved in a more welcoming department or are seeking to establish a Native perspective in an American Indian Studies department. Political science majors/minors can be found in post-secondary institutions with American Indian Studies Departments where their perspectives are not confined by the establishment.

Finally, I need to address Ferguson's perspective that the change must come from within the profession because 
I have noted, as has he, that the number of people in the field who are American Indian is small; therefore, the change would have to come from a broadening of the perspectives of those already in the field who are not American Indian. The likelihood that those individuals who continue the established colonial perspectives would suddenly as individuals, or miraculously as a profession, have an epiphany and change direction strikes me as fiction (or science fiction). We can look to organizational change theory to recognize that even individuals who wish to change an organization end up being changed far more than the organization.

Individual change theory also proposes that individuals, such as the ones described here, must have significant lifechanging events to change behaviors. This recognition of both individual and organizational change prompts me to again assert that activism, particularly by those America Indian faculty who have survived, will bring real change. 